\title{
Effects of sexuality on frailty and quality of life in the elderly: a cross-sectional study
}

\author{
Efeitos da sexualidade na fragilidade e qualidade de vida da pessoa idosa: estudo seccional \\ Efectos de la sexualidad en la fragilidad y calidad de vida de la persona anciana: estudio seccional
}

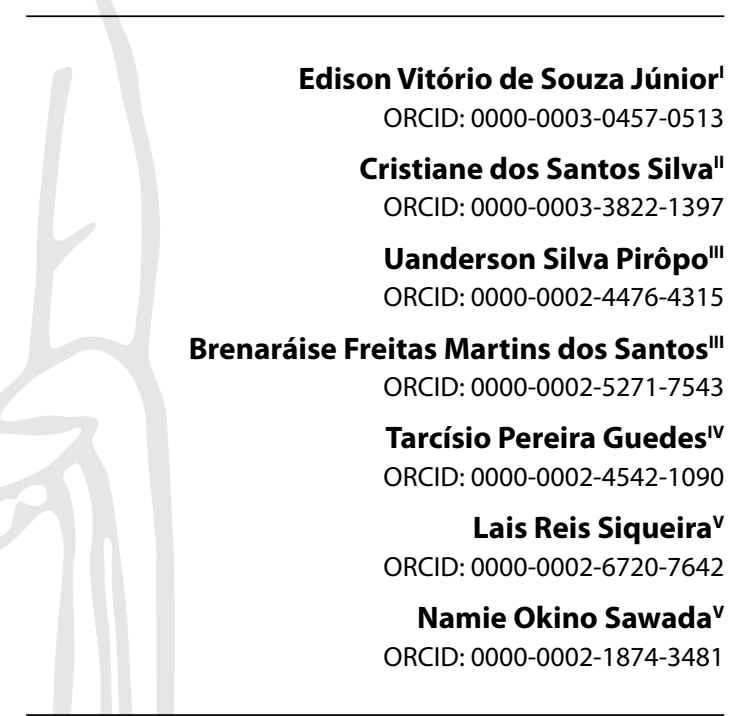

'Universidade de São Paulo. Ribeirão Preto, São Paulo, Brazil. "Universidade Norte do Paraná. Jequié, Bahia, Brazil. "'Universidade Estadual do Sudoeste da Bahia. Jequié, Bahia, Brazil.

"Universidade Estadual de Feira de Santana. Feira de Santana, Bahia, Brazil.

vUniversidade Federal de Alfenas. Alfenas, Minas Gerais, Brazil.

How to cite this article: Souza Júnior EV, Silva CS, Pirôpo US, Santos BFM, Guedes TP, Siqueira LR, et al. Effects of sexuality on frailty and quality of life in the elderly: a cross-sectional study.

Rev Bras Enferm. 2022;75(1):e20210049.

https://doi.org/10.1590/0034-7167-2021-0049

Corresponding author:

Edison Vitório de Souza Júnior

E-mail: edison.vitorio@usp.br

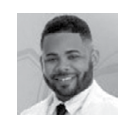

EDITOR IN CHIEF: Antonio José de Almeida Filho ASSOCIATE EDITOR: Álvaro Sousa

\begin{abstract}
Objectives: to analyze the effects of sexuality on frailty and quality of life in the elderly. Methods: a sectional study conducted with 662 elderly people between July and October 2020. Four self-administered instruments were used to collect bio-sociodemographic variables, sexuality, frailty and quality of life. Correlation analysis and structural equation modeling were performed. Results: among the dimensions that assess sexuality, sexual intercourse had a weak, positive effect on quality of life (SC: $0.134,95 \% \mathrm{Cl}: 0.153-0.254, \mathrm{p}=0.027$ ), while affective relationships had a strong, positive effect (SC: $0.556,95 \% \mathrm{Cl}: 0.442-0.670, \mathrm{p}$ $<0.001)$. Frailty was only significantly related to a weak to moderate negative effect with sexual intercourse (SC: $-0.216,95 \% \mathrm{Cl}:-0.385--0.047, p=0.012$ ). Conclusions: two dimensions of sexuality, Sexual intercourse and Affective relationships, were found to have an effect on the quality of life and frailty of the elderly people investigated.
\end{abstract}

Descriptors: Health of the Elderly; Public Health; Sexuality; Frailty; Comprehensive Health Care.

\section{RESUMO}

Objetivos: analisar os efeitos da sexualidade na fragilidade e qualidade de vida da pessoa idosa. Métodos: estudo seccional conduzido com 662 pessoas idosas entre julho e outubro de 2020. Utilizaram-se quatro instrumentos autoaplicáveis para coleta das variáveis biossociodemográficas, sexualidade, fragilidade e qualidade de vida. Realizou-se uma análise de correlação e modelagem de equações estruturais. Resultados: dentre as dimensões que avaliam a sexualidade, $\mathrm{o}$ ato sexual exerceu efeito fraco e positivo sobre a qualidade de vida (CP: 0,134, IC95\%:0,153 - 0,254, $p=0,027$ ), enquanto as relações afetivas tiveram efeito forte e positivo (CP:0,556, IC95\%:0,442 $-0,670, p<0,001)$. A fragilidade só foi significantemente relacionada a um efeito negativo, de fraco a moderado, com o ato sexual (CP:- $-0,216$, IC95\%: $-0,385--0,047, p=0,012)$. Conclusões: constatouse que duas dimensões da sexualidade, Ato sexual e Relações afetivas, exerceram efeitos sobre a qualidade de vida e fragilidade das pessoas idosas investigadas.

Descritores: Saúde do Idoso; Saúde Pública; Sexualidade; Fragilidade; Assistência Integral à Saúde.

\section{RESUMEN}

Objetivos: analizar efectos de la sexualidad en la fragilidad y calidad de vida del anciano. Métodos: estudio seccional conducido con 662 ancianos entre julio y octubre de 2020. Utilizaron cuatro instrumentos autoaplicables para recogida de las variables biosociodemográficas, sexualidad, fragilidad y calidad de vida. Realizó un análisis de correlación y modelado de ecuaciones estructurales. Resultados: de entre las dimensiones que evalúan la sexualidad, el acto sexual ejerció efecto débil y positivo sobre la calidad de vida (CP: 0,134, IC95\%:0,153 $0,254, p=0,027)$, mientras las relaciones afectivas tuvieron efecto fuerte y positivo ( $C P: 0,556$, IC95\%:0,442-0,670, $p<0,001)$. La fragilidad sólo fue relevante relacionada a un efecto negativo, de débil a moderado, con el acto sexual (CP: -0,216, IC95\%:-0,385--0,047, $p=0,012$ ). Conclusiones: constató que dos dimensiones de la sexualidad, Acto sexual y Relaciones afectivas, ejercieron efectos sobre la calidad de vida y fragilidad de los ancianos investigados. Descriptores: Salud del Anciano; Salud Pública; Sexualidad; Fragilidad; Atención Integral de Salud. 


\section{INTRODUCTION}

The changes resulting from aging observed in human beings involve social, physical and psychological aspects and make them more vulnerable ${ }^{(1)}$. Although aging is associated with frailty, these two terms cannot be treated as synonymous ${ }^{(2)}$. However, it is estimated that $10 \%$ of people over the age of 65 and $25 \%$ to $50 \%$ among those over the age of 85 are frail $^{(3)}$. It is a condition with high prevalence among longevous people - a population characterized by a rapid and progressive rate of growth among the elderly ${ }^{(4)}$.

Frailty is involved by multidimensionality that encompasses environmental, biological, psychological, physical, economic, cognitive and social factors, making the elderly person vulnerable to negative outcomes ${ }^{(2)}$, as dependency ${ }^{(4)}$, mortality ${ }^{(5)}$, institutionalization ${ }^{(6)}$, falls $s^{(7)}$, incapacity ${ }^{(5)}$, delirium ${ }^{(8)}$, chronic diseases, osteopenia and anorexia ${ }^{(9)}$, reduced functional capacity and dependence ${ }^{(2)}$. It is, therefore, an important public health problem due to the multiple clinical and social consequences caused by frailty, in addition to its dynamic nature ${ }^{(10)}$.

In the frailty syndrome, there is an inability to maintain organic homeostasis and decreased resistance to stressful events. As a result, there is a decline of the physiological system evidenced by the triad of several aging-related modifications: sarcopenia, immune dysfunction, and neuroendocrine deregulation ${ }^{(1)}$. In this study, the theoretical framework for frailty will be the one proposed by Fried ${ }^{(3)}$, whose approach is directed towards physical aspects and is identified by the presence of three or more of the five assessment components: unintentional weight loss, self-reported exhaustion, weakness, slow walking speed, and low physical activity ${ }^{(3)}$. The choice of this reference is justified because the instrument ${ }^{(11)}$ used in this study was constructed and validated according to these parameters, which ensured articulation between theory and the constructs evaluated.

Also with regard to frailty, it is revealed that the identification, assessment and treatment of elderly people with some degree of frailty tend to become the focus of geriatric and gerontological care in this century ${ }^{(4)}$, pointing to "identification" as one of the fundamentals of health care to be provided to this population ${ }^{(10)}$. This field of study, therefore, needs in-depth investigations to identify preventable factors and the tools needed to develop interventions ${ }^{(9)}$.

From this perspective, our hypothesis is that one of these interventions may be sexuality, considered a human dimension that goes beyond the body and physical contact ${ }^{(12)}$, associated with health maintenance ${ }^{(13)}$ and well-being ${ }^{(14)}$, which changes according to the social, cultural, and religious aspects that permeate the individual's life ${ }^{(12)}$. It is a set of cognitive, sentimental and behavioral manifestations, such as touch, affection, harmony in the relationship, companionship, love, complicity, trust and other quantitative-qualitative expressions, including sexual activity itself ${ }^{(15-16)}$. Furthermore, it is through sexuality that a person demonstrates his/her identity, being expressed in a unique and particular way, present in all phases of life ${ }^{(17)}$.

However, in general, the sexuality of the elderly is reduced to the biological component, including by health professionals. Nevertheless, the lack of information provides the increase and dissemination of stereotypes related to sexuality in this age group, such as the erroneous thought that imputes the condition of asexuality to this population. However, it should be noted that, on the one hand, although aging causes peculiar changes, the elderly person remains with the desire ${ }^{(17)}$. On the other hand, the physiological decline caused by the aging process can somehow influence the experiences in sexuality, the presence or absence of frailty and the quality of life (QOL) of the elderly.

QoL is a multidimensional and subjective construct considered an important health indicator ${ }^{(18-19)}$. It is about each person's individual perception of the balance between the different aspects that shape their daily life, such as leisure, work, spirituality, sexual activity, family, among others ${ }^{(20)}$.

One of the most used theoretical references for research on QoL, which will be adopted in this study, is the World Health Organization (WHO), which defines QoL as "an individual's perception of his position in life in the context of the culture and value systems in which he lives and in relation to his goals, expectations, standards, and concerns"(21). This choice is justified by the comprehensiveness of its definition, which encompasses, above all, the context of culture and the value systems in which the individual lives, these being factors that may influence the experiences of sexuality by the elderly. The second justification is that the instrument used to assess sexuality was built and validated together with the same instrument developed by the WHO that will assess QoL in this study, and a high correlation was evidenced between them ${ }^{(22)}$. Thus, it is observed that there is robust methodological articulation to evaluate the intended constructs.

Whereas the state of the art presents gaps in the field of sexuality in old age, since most studies address only the aspects of the medical model of sexuality and the physiological repercussions of aging on the sexual response of men and women ${ }^{(23)}$, the development of this study becomes relevant, especially for the improvement of nursing practices.

Nursing is a science whose practices are based on the principle of humanization, empathy, as well as technical and scientific knowledge, which guarantee efficiency in assisting people. Thus, considering that sexuality is a basic need of the human being ${ }^{(13)}$ and that, due to this characteristic, corroborates the Theory of Basic Human Needs, by Wanda Horta, one of the main nursing theoreticians, it becomes relevant that nurses are prepared to approach this theme with the elderly, thus exercising their functions as educators and providers of holistic and humanized care.

In addition, nurses must insert approaches to sexuality as a social practice and understand its unfoldings that help in the innovation of comprehensive care strategies for the elderly without reducing them to the sexual component, but contemplating the aspects of body, pleasure and displeasure, among others that involve sexuality in all its amplitude ${ }^{(24)}$. This is because nurses have an impact on health promotion, and the longitudinality of this professional's care in Primary Care promotes the strengthening of relationships and trust that can stimulate the expression of intimate needs by older people, such as sexuality ${ }^{(12)}$.

Therefore, our hypothesis is that sexuality has effects on frailty and QoL of elderly people. If a significant association is found, this study may contribute to improve the scientific evidence on 
the theme and encourage health professionals, especially nurses, to take this approach during their care practices.

\section{OBJECTIVES}

To analyze the effects of sexuality on frailty and quality of life in the elderly.

\section{METHODS}

\section{Ethical aspects}

This study strictly followed all ethical and bioethical aspects of research with human beings, as recommended by Resolution 466/2012 of the National Health Council. All participants received detailed information about the risks, benefits, relevance and justification for the development of the study and signed an online Free and Informed Consent Term (FICT), keeping an electronic copy that was sent directly to the personal e-mail address requested when filling out the questionnaire.

\section{Study design, time and place}

This is an analytical and sectional study developed according to the recommendations of the STROBE checklist. Data collection was conducted exclusively online in the period from July to October 2020 through a social interaction page created on Facebook for the development of scientific research on sexuality in the elderly. Thus, there were no face-to-face meetings, and the individuals participated in the study in their respective homes through internet connection and active account on that social network.

\section{Sample; inclusion and exclusion criteria}

The sample of participants was calculated considering an infinite population, $a=5 \%$ and $95 \% \mathrm{Cl}(z a / 2=1.96)$, which resulted in a minimum sample size of 385 participants. However, considering the possibility of losses and incomplete answers in the questionnaire, there was an addition of more than $50 \%(n=$ 277) to the sample, totaling a final sample size of 662 Brazilian elderly people.

The participants were selected according to the non-probability consecutive sampling technique, in which the invitation to participate in the study was made by disclosing the hyperlink on a Facebook page. Because the participants interact actively in social networks and have skills in handling equipment that give access to these networks (computer, laptop, tablet and/or cell phone), the application of instruments to assess cognition was waived.

The inclusion criteria adopted were: people 60 years old or older; community residents; with internet access and an active Facebook account; with a steady partner, in a stable union or married, and without gender restrictions (male, female, and others). The option "others" referred to those who identified themselves as non-binary or who did not fit into any stratification. Dependent elderly people and those living in long-stay institutions were excluded from the study.

\section{Study protocol}

On the page created, the authors published the hyperlink that gave direct access to the questionnaire, organized in the Google Forms tool and divided into four surveys. The first survey referred to the collection of bio-sociodemographic information, such as marital status, sexual orientation, religion, age, gender, ethnicity, number of children, education, sexual orientation, and geographic location.

The second survey was built in order to assess the participants' sexuality through the Affective and Sexual Experiences Scale for Elderly (ASESE), built and validated in Brazil in 2012(22). This is a psychometric scale with 38 items distributed in three dimensions: Sexual act; Affective relationships; and Physical and social adversities. The answers are organized according to the Likert model, ranging from 1 (never) to 5 points (always) and with no cutoff point. The results are interpreted according to the criterion that the higher the score, the better are the experiences of sexuality by the elderly ${ }^{(22)}$.

The third survey aimed at assessing frailty by means of the Selfreported Frailty Instrument, built and validated for the Brazilian elderly population. It is an instrument composed of six questions organized into five components: Weight loss; Reduced strength; Reduced walking speed; Low physical activity; and Reported fatigue. The frailty classification can be: frail people (equal to or greater than three components), pre-frail (between one and two components) and non-frail (those who did not present any of the described components) $)^{(11)}$.

Finally, the fourth survey was built to evaluate the QoL of the participants by means of the standardized instrument validated for the Brazilian population World Health Organization Quality of Life - Old (WHOQOL-Old) ${ }^{(25)}$. This instrument was built with 24 items distributed in six facets: Sensory abilities; Autonomy; Past, present and future activities; Social participation; Death and dying; and Intimacy ${ }^{(26)}$. Each item has five possible answers organized in a Likert scale, whose total score ranges from 24 to 100 points. The higher the score, the better the individual's QoL; and, conversely, the lower score reflects the worst perception of $\mathrm{QoL}^{(26)}$.

It is noteworthy that, before the participants started answering the questionnaire, their e-mail address was required so that the researchers could track and control the data, avoiding multiple filling out by the same participant. In addition, the authors hired the service of post boosting, in which Facebook disseminated the survey invitation to all people with an active account who met the inclusion criteria previously informed in the field of delimitation of the post.

\section{Analysis of results and statistics}

Data were stored and analyzed in IBM SPSS ${ }^{\circledR}$ and STATA statistical software. After verifying the non-normality of the data through the Kolmogorov-Smirnov test $(p<0.05)$, we used: medians and interquartile range (IQR) to evaluate quantitative variables; absolute and relative frequencies for qualitative variables.

In order to verify the relationships between sexuality, frailty and QoL, a correlation analysis was carried out to know the paths to be drawn in the structural equation modeling (SEM). Then, the 
model was built, composed of: a latent variable, QoL, formed by the statistically significant domains; and by four observable variables three domains of the ASESE and the frailty assessment. The results were presented with the standardized coefficients (SC) and their respective $95 \%$ confidence intervals $(95 \% \mathrm{Cl})$, being interpreted according to Kline ${ }^{(27)}$, where a SC of 0.10 indicates a small effect; of 0.30, a medium effect; and, greater than 0.50 , a strong effect.

The adequacy of the proposed model was verified by means of the following fit indices: the Comparative Fit Index (CFI) and the Tucker-Lewis index (TLI), with values closer to 1 indicating better $\mathrm{fit}^{(28)}$; the Standardized root mean square residual (SRMR), with a value less than 0.08 indicating a good fit and less than 0.10 , an acceptable fit ${ }^{(27)}$; the Root-Mean-Square Error of Approximation (RMSEA), with its $90 \%$ confidence interval (CI90\%) and with the interpretation in which 0 - perfect fit, $<0.05$ - good fit, 0.05-0.08 - moderate fit, 0.08-0.10 - poor fit, and >0.10 - inadequate fit ${ }^{(29)}$ and the absolute fit index, Adjusted Goodness-of-Fit Index (AGFI), which ranges from 0 to 1 , and it is generally accepted that values of 0.90 or greater indicate well-fit models ${ }^{(30)}$.

\section{RESULTS}

Among the 662 participants, there was a predominance of frail individuals ( $n=299 ; 45.2 \%$ ), followed by pre-frail ( $n=265 ; 40 \%$ ) and non-frail ( $n=98 ; 14.8 \%$ ). Regarding the biosociodemographic characteristics, there was a higher prevalence of elderly males ( $\mathrm{n}$ $=383 ; 57.9 \%)$, aged between 60 and 64 years $(n=318 ; 48.8 \%)$, self-declared white ( $n=447 ; 67.5 \%)$, married ( $n=420 ; 63.4 \%$ ), with higher education ( $n=276 ; 41.7 \%$ ), living in the Southeast Region ( $n=297 ; 44.9 \%$ ), and who never received guidance on sexuality from health professionals $(n=518 ; 78.2 \%)$. The other characteristics are shown in Table 1.

According to Table 2, in relation to sexuality, it is noted that the non-fragile participants showed the highest scores in the Sexual act and Affective relationships dimensions, demonstrating a better experience when compared to pre-fragile and fragile participants. Moreover, the lower scores in the Physical and Social Adversities indicate that non-fragile individuals better cope with such adversities related to their experiences in sexuality. Similarly, the non-fragile individuals showed better QoL in most facets when compared to participants with some degree of frailty. We observed similarity of scores only between the non-fragile and pre-fragile participants in the facet Social Participation; besides the facet Intimacy, which showed the same score for all participants regardless of the degree of fragility (Table 2).

The correlations between sexuality, QoL and frailty are negative and significant in their totality, with the exception of the relationship of dimension 3 (ASESE3) of the sexuality scale (Physical and social adversities), as shown in Table 3.

In the measurement model, the latent QoL showed adequate factor loadings (>0.45) only for the facets Past, present and future activities (DOM 3), Social participation (DOM 4) and Intimacy (DOM 6). The latent frailty, in turn, was adequately formed by the domains Reduced strength (Frail 2); Reduced speed and walking (Frail 3) and Low physical activity (Frail 4) being, therefore, maintained in the model. These variables together with the domains of ASESE composed the measurement model proposed here (Figure 1). It was possible to evidence the good adjustment of the model by evaluating the adjustment indexes RMSEA (0.05 [95\%Cl 0.04-0.07]), CFI (0.982) and SRMR (0.05).

As for the effects, we notice in Table 4 that the dimension Sexual act (ASESE1) has a weak and positive effect on QoL, while the dimension Affective relationships (ASESE 2) has a strong and positive effect. Frailty, on the other hand, was only significantly related to a negative effect, from weak to moderate, with the dimension Sexual act (ASESE 1).

Table 1 - Biosociodemographic characteristics of the participants, Ribeirão Preto, São Paulo, Brazil, 2020

\begin{tabular}{lcc}
\hline Variables & $\mathbf{n}$ & $\%$ \\
\hline Religion & & \\
$\quad$ Catholic & 360 & 54.4 \\
Protestant & 89 & 13.4 \\
Spiritist & 80 & 12.1 \\
African-origin religions & 12 & 1.8 \\
Others & 59 & 8.9 \\
Without religion & 62 & 9.4 \\
How long you have lived with your partner & & \\
S5 years & 110 & 16.6 \\
Between 6 and 10 years old & 58 & 8.8 \\
Between 11 and 15 years old & 34 & 5.1 \\
Between 16 and 20 years old & 42 & 6.3 \\
$>$ 20 years & 418 & 63.1 \\
Lives with her children & & \\
Yes & 178 & 26.9 \\
No & 449 & 67.8 \\
Has no children & 35 & 5.3 \\
Sexual orientation & & \\
Heterosexual & & \\
Homosexual & 575 & 86.9 \\
Bisexual & 13 & 2.0 \\
Others & 12 & 1.8 \\
\hline
\end{tabular}

Table 2 - Evaluation of sexuality and quality of life according to the fragility of the participants, Ribeirão Preto, São Paulo, Brazil, 2020

\begin{tabular}{|c|c|c|c|c|}
\hline Variables & $\begin{array}{c}\text { Not frail* } \\
\text { Median (IQR) }\end{array}$ & $\begin{array}{c}\text { Pre frail* } \\
\text { Median (IQR) }\end{array}$ & $\begin{array}{c}\text { Frail* }^{*} \\
\text { Median (IQR) }^{2}\end{array}$ & $\begin{array}{c}\text { General* } \\
\text { Median (IQR) }\end{array}$ \\
\hline \multicolumn{5}{|l|}{ Sexuality } \\
\hline Sexual act & $79.00(72.00-82.00)$ & $74.00(66.00-81.00)$ & $72.00(58.00-78.00)$ & $74.00(63.75-80.00)$ \\
\hline Affective Relationships & $80.00(74.00-83.00)$ & $77.00(67.00-82.00)$ & $72.00(58.00-79.00)$ & $75.50(65.00-81.00)$ \\
\hline Physical and Social Adversities & $5.00(3.75-7.00)$ & $6.00(5.00-8.00)$ & $8.00(7.00-10.00)$ & $7.00(5.00-9.00)$ \\
\hline \multicolumn{5}{|l|}{ Quality of Life } \\
\hline Sensory Abilities & $93.75(75.00-95.31)$ & $81.25(75.00-93.75)$ & $75.00(56.25-87.50)$ & $81.25(68.75-93.75)$ \\
\hline Autonomy & $75.00(62.50-82.81)$ & $68.75(56.25-75.00)$ & $62.50(50.00-75.00)$ & $68.75(56.25-75.00)$ \\
\hline Past, present and future activities & $75.00(62.50-81.25)$ & $68.75(56.25-81.25)$ & $62.50(50.00-75.00)$ & $68.75(56.25-81.25)$ \\
\hline Social Participation & $75.00(68.75-81.25)$ & $75.00(62.50-81.25)$ & $62.50(50.00-75.00)$ & $68.75(56.25-75.00)$ \\
\hline Death and Dying & $81.25(56.25-93.75)$ & $75.00(56.25-90.62)$ & $68.75(43.75-81.25)$ & $75.00(50.00-87.00)$ \\
\hline Intimacy & $75.00(75.00-87.50)$ & $75.00(68.75-81.25)$ & $75.00(56.25-75.00)$ & $75.00(62.50-81.25)$ \\
\hline General QoL & $77.08(70.57-83.59)$ & $72.91(63.54-80.20)$ & $64.58(55.20-73.95)$ & $69.79(60.41-79.16)$ \\
\hline
\end{tabular}


Table 3 - Pearson's correlation coefficient $(r)$ between sexuality, frailty and quality of life, Ribeirão Preto, São Paulo, Brazil, 2020

\begin{tabular}{lcccccc}
\hline & \multicolumn{2}{c}{ Frail 2 } & \multicolumn{2}{c}{ Frail 3 } & \multicolumn{2}{c}{ Frail 4 } \\
& $\mathbf{r}$ & $\boldsymbol{p}$ & $\mathbf{r}$ & $\boldsymbol{p}$ & $\mathbf{r}$ & $\boldsymbol{p}$ \\
\hline DOM 3 & -0.226 & $<\mathbf{0 . 0 0 1}$ & -0.175 & $<\mathbf{0 . 0 0 1}$ & -0.132 & $<\mathbf{0 . 0 0 1}$ \\
DOM 4 & -0.251 & $<\mathbf{0 . 0 0 1}$ & -0.175 & $<\mathbf{0 . 0 0 1}$ & -0.189 & $<\mathbf{0 . 0 0 1}$ \\
DOM 6 & -0.203 & $<\mathbf{0 . 0 0 1}$ & -0.199 & $<\mathbf{0 . 0 0 1}$ & -0.125 & $<\mathbf{0 . 0 1}$ \\
ASESE1 & -0.205 & $<\mathbf{0 . 0 0 1}$ & -0.235 & $<\mathbf{0 . 0 0 1}$ & -0.124 & $<\mathbf{0 . 0 0 1}$ \\
ASESE 2 & -0.202 & $<\mathbf{0 . 0 0 1}$ & -0.220 & $<\mathbf{0 . 0 0 1}$ & -0.106 & $<\mathbf{0 . 0 0 1}$ \\
ASESE 3 & 0.140 & $<\mathbf{0 . 0 0 1}$ & 0.210 & $<\mathbf{0 . 0 0 1}$ & 0.108 & $<\mathbf{0 . 0 1}$
\end{tabular}

Frail 2 - Reduced strength; Frail 3 - Reduced walking speed; Frail 4 - Low physical activity; DOM 3 - Past, present and future activities; DOM 4 - Social participation; DOM 6 - Intimacy; ASESE 1 Sexual act; ASESE 2 - Affective relationships; ASESE 3 - Physical and social adversities.

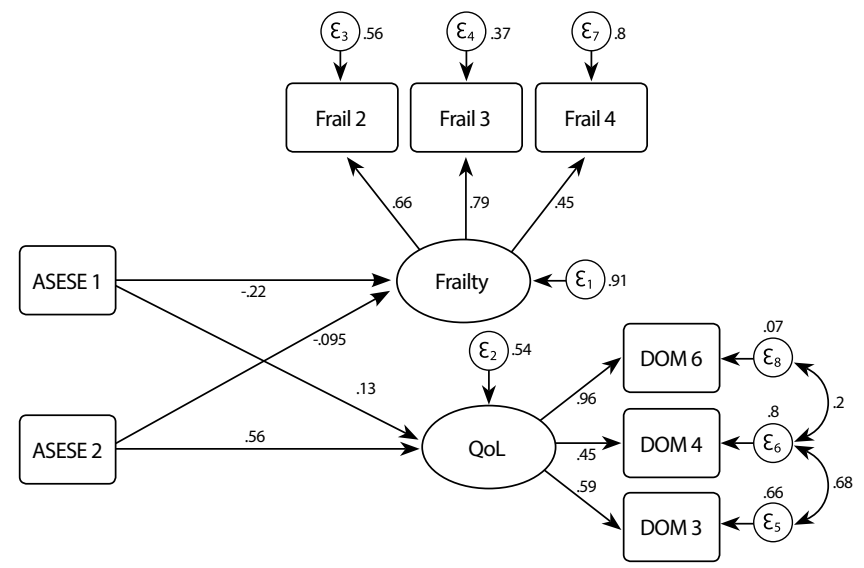

Figure 1 - Structural equation model for sexuality, frailty and quality of life, Ribeirão Preto, São Paulo, Brazil, 2020

Table 4 - Standardized coefficients of structural equation modeling between sexuality, frailty and quality of life, Ribeirão Preto, São Paulo, Brazil, 2020

\begin{tabular}{lccc}
\hline & SC & $\mathbf{9 5 \% C l}$ & $\boldsymbol{p}$ \\
\hline Measurement model & & & \\
DOM $3 \leftarrow \mathrm{QoL}$ & 0.585 & $0.524-0.645$ & $<\mathbf{0 . 0 0 1}$ \\
DOM $4 \leftarrow$ QoL & 0.447 & $0.363-0.532$ & $<\mathbf{0 . 0 0 1}$ \\
DOM $6 \leftarrow$ QoL & 0.964 & $0.363-0.532$ & $<\mathbf{0 . 0 0 1}$ \\
Frail $2 \leftarrow$ QoL & 0.660 & $0.585-0.736$ & $<\mathbf{0 . 0 0 1}$ \\
Frail $3 \leftarrow$ QoL & 0.792 & $0.713-0.871$ & $<\mathbf{0 . 0 0 1}$ \\
Frail 4 $\leftarrow$ QoL & 0.452 & $0.376-0.528$ & $<\mathbf{0 . 0 0 1}$ \\
Structural Model & & & \\
$\quad$ Frailty $\leftarrow$ ASESE 1 & -0.216 & $-0.385--0.047$ & 0.012 \\
Frailty $\leftarrow$ ASESE 2 & -0.095 & $-0.266-0.074$ & 0.272 \\
QoL $\leftarrow$ ASESE 1 & 0.134 & $0.153-0.254$ & 0.027 \\
QoL $\leftarrow$ ASESE 2 & 0.556 & $0.442-0.670$ & $<\mathbf{0 . 0 0 1}$ \\
\hline
\end{tabular}

SC - standardized coefficients; QoL - quality of life; DOM 3 - Past, present and future activities; DOM 4 - Social participation; DOM 6 - Intimacy; ASESE 1 - Sexual act; ASESE 2 - Affective relationships; ASESE 3 - Physical and social adversities.

\section{DISCUSSION}

Our results indicated that sexual intercourse exerts a weak and negative effect on the frailty of the elderly, which was globally analyzed in the present study. This means that these two variables present an inversely proportional behavior, that is, as the individuals maintain sexual relationships, these will exert a reducing effect on frailty. There are no studies that investigate the effects of sexuality on the frailty of the elderly in order to identify new non-pharmacological measures to promote health and QoL to this population, which makes our study pioneer in the theme.

The closest research to our theme was carried out in a multicenter partnership with Italy, Belgium, Poland, Sweden, the
United Kingdom, Spain, Hungary and Estonia, which revealed an association between frailty and reduced overall sexual functioning, increased distress related to sexual function, and increased chances of erectile dysfunction ${ }^{(31)}$.

We know that, in the physiological context, there are several factors that can hinder the sexual expression of the elderly person. In men, genital atrophy occurs; testosterone is reduced; erectile retardation and malfunction; reduced libido, and inability to maintain arousal. In women, we observe reduced estrogen secretion after menopause; atrophy of the vaginal canal; and decreases in lubrication, cervix contraction, and breast size ${ }^{(32)}$. However, there is hardly any deterioration of sexual desire in healthy aging of such a magnitude as to make sexual practice impossible among the elderly ${ }^{(33)}$. On the contrary, they continue to have the desires and interest to actively continue their sex life ${ }^{(32)}$.

This is corroborated by a study ${ }^{(33)}$ developed with 187 Brazilian and Portuguese elderly persons, in which it was revealed that at least $24 \%$ of Brazilian women, $38 \%$ of Portuguese women, and $75 \%$ of Portuguese men have sexual intercourse at least once a month. Furthermore, the authors identified that about $20 \%$ of women and $46 \%$ of men have sexual intercourse at least once a week, and more than $50 \%$ of all respondents would like to experience at least once a week ${ }^{(33)}$. We thus emphasize that maintaining sexual relations until the end of life can constitute a practice that promotes benefits for successful aging ${ }^{(34)}$.

Among the factors that support successful aging, there is QoL. Sexual activity is already considered an important indicator of QoL in the elderly population and is associated with reduced risk of chronic diseases, satisfaction in relationships, and promotes physical and mental well-being ${ }^{(32)}$. Nevertheless, low quality of sex life is associated with depression and predicts instability in relationships; and a good quality of sex life is associated with greater satisfaction, love, commitment, and stable relationships ${ }^{(35)}$.

We emphasize that deeper investigations on sexual activity are capable of revealing subsidies that ratify its importance for improving the well-being of the elderly, based on the maintenance of an active sexual life as a way to promote health and QoL. However, there are still not enough scientific data that evaluate these variables ${ }^{(36)}$. One Study ${ }^{(37)}$ conducted with 203 Jews $( \pm 69.59$ years) revealed that the frequency of sexual activity is a predictor of QoL, indicating a mediating effect in the relationship between attitudes towards sexuality and the QoL of the elderly.

Another study conducted with 3,045 men and 3,834 women with a mean age of 64.4 and 65.3 years, respectively, showed that several component domains of the sexual activity assessment were associated with well-being, especially the enjoyment of life. In addition, participants of both sexes who had some sexual activity in the past year reported greater enjoyment of life when compared to sexually inactive participants ${ }^{(36)}$.

There are several reasons for this evidence, such as the release of endorphins, which promote feelings of happiness, joy, and bliss after sex; the intimacy between partners, which becomes more intense; and the fact that sex is considered a form of physical activity with beneficial repercussions for the physical and psychological components ${ }^{(36)}$.

In this sense, from the moment that these components suffer positive influences through sexual activity, we infer that frailty 
and QoL may be two aspects that behave, respectively, in an inverse manner and directly proportional to sex, that is, as the individual maintains frequency in his sexual relations, there is a tendency to reduce the symptoms of frailty and increase his perception of QoL.

However, it is a topic that continues to be neglected in research, media and policy development, despite the fact that we are in a reality in which the current generation of older people value health and sexual activity more than previous generation $s^{(38)}$. Therefore, we must remember that most elderly people are sexually active and sexually satisfied, and that sexual activity and the intimacy resulting from this encounter of bodies play an important role in life satisfaction and psychological well-being ${ }^{(39)}$. Thus, the implementation of educational and protective actions regarding the vulnerabilities of sexuality in this age group becomes extremely necessary ${ }^{(40)}$.

We know that although sexual activity is a central component of intimate relationships, it declines in old age ${ }^{(36)}$. However, in this age group, there are small adaptations that promote new forms of pleasure, going beyond genitality as the main focus and considering new ways related to touch, affection and care ${ }^{(34)}$. It is from there that affective relationships come into play as components of sexuality.

In our study, affective relationships had a strong and positive effect on the QoL of the participants, as shown in Table 4. This is an ASESE dimension that assesses the following aspects: pleasure in being with the partner, privacy, affection, friendship, partnership, love, importance of sexuality in QoL, complicity, companionship, acceptance of the changes resulting from aging, expression of feelings, among other qualitative aspects that refer to the affection between spouses ${ }^{(22)}$.

From this perspective, a study ${ }^{(36)}$ identified that, among sexually active elderly people, the greater frequency of the affective component such as caresses, kisses and affection was associated with greater pleasure in life in both sexes, besides being associated with greater frequency in sexual intercourse only for men. In fact, the literature points out that the sexual act itself is more valued by men, and there are studies ${ }^{(41-42)}$ that ratify this evidence. For women, sex is more related to intimacy, love, affection, and care, while for men it is related to the physical aspects that surround $\mathrm{it}^{(41,43)}$. Thus, we reaffirm the need for the training of health professionals so that they can develop effective strategies for welcoming and providing appropriate guidance, free of judgments and prejudices regarding the sexuality of the elderly, since it is a physiological and emotional need of the individual that strongly contributes to $\mathrm{QoL}^{(34)}$.

Also in this sense, the orientations of health professionals should be based on the orientation of the elderly in relation to the use of online social media. According to a Brazilian study developed by the Credit Protection Service (SPC) and the National Confederation of Store Managers (CNDL), 39\% of the elderly people interviewed used the Internet. In addition, 77\% interacted actively on Facebook, followed by WhatsApp (73\%) and Youtube (40\%), and the use of smartphones to access the internet was the most prevalent $(61 \%)$, followed by traditional computers (53\%) ${ }^{(44)}$.

However, we emphasize that the increase in internet use by older people may have two sides, since, on the one hand, this reality may be beneficial to their QoL because it promotes autonomy and a sense of self-esteem, besides stimulating their neurocognitive abilities such as typing, reading, comprehension, and social interaction. On the other hand, participation in dating apps can predispose this population to sexually transmitted infections (STIs) and, consequently, promote negative impacts on their QoL. This is because older people may not value STI prevention methods, especially due to the sociocultural context in which they grew up, which may reflect in current risk behaviors.

Our inference supports an investigation ${ }^{(45)}$ developed in Brazil with 412 men who have sex with other men, with an average age of 61.6 years. This study considered participants who use dating apps such as Grindr', Hornet ${ }^{\circ}$, Scruff and Daddy Hunter ${ }^{\circ}$, thus revealing that the elderly population is increasingly interacting on social networks. However, the use of these applications, although an easy and agile tool to find affective-sexual partnerships, may also be accompanied by risk behaviors for STIs ${ }^{(45)}$ and, consequently, compromised QoL. This evidence points to the need for special attention from nurses during their consultations, since the neglect of this approach makes the elderly themselves not perceive themselves as vulnerable and, therefore, continue in risky behaviors ${ }^{(34)}$.

\section{Limitations of the study}

First, we consider that, due to the non-probabilistic design, the possibility of generalizing our results was weakened. Moreover, we consider that, due to the online collection through Facebook, there may have been limitation of participants only to people with greater socioeconomic power and high level of education, thus excluding the elderly with greater vulnerability in these aspects.

\section{Contributions to the field of nursing}

Our study contributes to the reorientation of care practices, especially in Primary Health Care. We believe that nursing professionals should recognize the benefits of sexuality for the elderly and the generational changes that have made them more willing to experience new experiences that were once strongly repressed by social prejudices. Sexuality should, therefore, be included in care plans and nursing consultations; it should also be discussed with the elderly whenever there are opportunities, stimulating them to self-knowledge and autonomy, through an approach free from prejudices that involve the theme.

\section{CONCLUSIONS}

We conclude that two dimensions of sexuality exerted effects on QoL and frailty of the investigated elderly: Sexual act, which had a weak and positive effect on QoL; and Affective relations, which had a strong and positive effect. In addition, frailty was only significantly related to a negative effect, of weak to moderate magnitude, with Sexual act.

In this sense, our findings suggest that the stimulation of sexuality, especially by the component related to affective relationships, can be encouraged among the elderly, since we observed a strong, positive and significant effect on the QoL of this public. In this sense, the involvement of the elderly in affective relationships 
Effects of sexuality on frailty and quality of life in the elderly: a cross-sectional study Souza Júnior EV, Silva CS, Pirôpo US, Santos BFM, Guedes TP, Siqueira LR, et al.

can contribute to the prevention and/or mitigation of situations that may have unsatisfactory repercussions on their mental health and, consequently, on their QoL, generating problems related to low self-esteem, loneliness, sadness, feelings of abandonment and uselessness, among others.

\section{FUNDING}

This work was carried out with the support of the Coordenação de Aperfeiçoamento de Pessoal de Nível Superior - Brazil (CAPES) - Financing Code 001.

\section{REFERENCES}

1. Fhon JRS, Rodrigues RAP, Santos JLF, Diniz MA, Santos EB, Almeida VC, et al. Factors associated with frailty in older adults: a longitudinal study. Rev Saude Publica. 2018;52:74. https://doi.org/10.11606/s1518-8787.2018052000497

2. Farías-Antúnez S, Fassa AG. Frailty prevalence and associated factors in the elderly in Southern Brazil, 2014. Epidemiol Serv Saúde. 2019;28(1):e2017405. https://doi.org/10.5123/s1679-49742019000100008

3. Fried LP, Tangen CM, Walston J, Newman AB, Hirsch C, Gottdiener J, et al. Frailty in older adults: evidence for a phenotype. J Gerontol A Biol Sci Med Sci. 2001;56(3):M146-56. https://doi.org/10.1093/gerona/56.3.m146

4. Duarte YAO, Nunes DP, Andrade FB, Corona LP, Brito TRP, Santos JLF, et al. Frailty in older adults in the city of São Paulo: Prevalence and associated factors. Rev Bras Epidemiol. 2018;21(supl.2):E180021. https://doi.org/10.1590/1980-549720180021.supl.2

5. Kojima G. Frailty as a predictor of disabilities among community-dwelling older people: a systematic review and meta-analysis. Disabil Rehabil. 2017;39(19):1897-908. https://doi.org/10.1080/09638288.2016.1212282

6. Kojima G. Frailty as a predictor of nursing home placement among community-dwelling older Adults. J Geriatr Phys Ther. 2018;41(1):42-8. https://doi.org/10.1519/JPT.0000000000000097

7. Cheng MH, Chang SF. Frailty as a risk factor for falls among community dwelling people: evidence from a meta-analysis. J Nurs Scholarsh. 2017;49(5):529-36. https://doi.org/10.1111/jnu.12322

8. Persico I, Cesari M, Morandi A, Haas J, Mazzola P, Zambon A, et al. Frailty and delirium in older adults: a systematic review and meta-analysis of the literature. J Am Geriatr Soc. 2018;66(10):2022-30. https://doi.org/10.1111/jgs.15503

9. Pereira RR, Silva CRR, Vasconcelos SC, Braga LAV, Monteiro EA, Pontes MLF. Cognition and frailty in community-dwelling elderly. Cogitare Enferm. 2019;24:e60578. https://doi.org/10.5380/ce.v24i0.60578

10. Faller JW, Pereira DN, Souza S, Nampo FK, Orlandi FS, Matumoto S. Instruments for the detection of frailty syndrome in older adults: a systematic review. PLoS One. 2019;14(4):e0216166. https://doi.org/10.1371/journal.pone.0216166

11. Nunes DP, Duarte YAO, Santos JLF, Lebrão ML. Screening for frailty in older adults using a self-reported instrument. Rev Saúde Pública. 2015;49(1). https://doi.org/10.1590/S0034-8910.2015049005516

12. Evangelista AR, Moreira ACA, Freitas CASL, Val DR, Diniz JL, Azevedo SGV. Sexuality in old age: knowledge/attitude of nurses of family health strategy. Rev Esc Enferm USP. 2019;53. https://doi.org/10.1590/s1980-220x2018018103482

13. Waite LJ, Iveniuk J, Laumann EO, McClintock MK. Sexuality in older couples: individual and dyadic characteristics. Arch Sex Behav. 2017;46:605-18. https://doi.org/10.1007/s10508-015-0651-9

14. Eymann A. Before and after assessment of a sexuality workshop in high-school students. Arch Argent Pediatr. 2019;117(5):477-84. https:// doi.org/10.5546/aap.2019.eng.e477

15. Cunha AMS, Lima ABA, Santos IMR, Gomes NMC, Souza EMS. Conversando sobre sexualidade e afetividade entre pessoas idosas. GepNews [Internet]. 2019 [cited 2020 Nov 6];2(2):153-60. Available from: https://www.seer.ufal.br/index.php/gepnews/article/view/7893

16. Lobaina EC, Cortés JTA, Hechavarría GÁP, González PF, Verdecia RR. Salud sexual en ancianos de un consultorio médico de la familia. MEDISAN [Internet]. 2017 [cited 2020 Nov 6];21(7):858. Available from: http://scielo.sld.cu/pdf/san/v21n7/san12217.pdf

17. Cabral NES, Pereira GCS, Souza US, Lima CFM, Santana GMS, Castañeda RFG. Understanding of sexuality by elderly men from a rural area. Rev Baiana. 2019;33e28165. https://doi.org/10.18471/rbe.v33.28165

18. Almeida-Brasil CC, Silveira MR, Silva KR, Lima MG, Faria CDCM, Cardoso CL, et al. Quality of life and associated characteristics: application of WHOQOL-BREF in the context of Primary Health Care. Ciênc Saúde Colet. 2017;22(5):1705-16. https://doi. org/10.1590/1413-81232017225.20362015

19. Neves LAS, Castrighini CC, Reis RK, Canini SRMS, Gir E. Social support and quality of life of people with tuberculosis. Enferm Glob. 2018;(50):11-20. https://doi.org/10.6018/eglobal.17.2.276351

20. Anversa $A B$, Mantovi $D$, Antunes $M$, Codonhato R, Oliveira DV. Quality of life and body image of women practicing strength training and gymnastics. Psicol saúde doenças. 2019;20(1):149-59. https://doi.org/10.15309/19psd200112

21. The Whoqol Group. The World Health Organization Quality of Life Assessment (WHOQOL): development and general psychometric properties. Soc Sci Med [Internet]. 1998 [cited 2017 Nov 25];46(12):1569-85. Available from: http://www.ncbi.nlm.nih.gov/pubmed/9672396

22. Vieira KFL. Sexualidade e qualidade de vida do idoso: desafios contemporâneos e repercussões psicossociais [Tese] [Internet]. Universidade Federal da Paraíba; 2012 [cited 2020 Oct 22]. Available from: https://repositorio.ufpb.br/jspui/bitstream/tede/6908/1/arquivototal.pdf 
23. Srinivasan S, Glover J, Tampi RR, Tampi DJ, Sewell DD. Sexuality and the Older Adult. Curr Psychiatry Rep. 2019; 21:97. https://doi. org/10.1007/s11920-019-1090-4

24. Souza CL, Gomes VS, Silva RL, Silva ES, Alves JP, Santos NR, et al. Envelhecimento, sexualidade e cuidados de enfermagem: o olhar da mulher idosa. Rev Bras Enferm. 2019;72(Suppl 2):71-78. https://doi.org/10.1590/0034-7167-2018-0015

25. Fleck MP, Chachamovich E, Trentini C. Development and validation of the Portuguese version of the WHOQOL-OLD module. Rev Saúde Pública. 2006;40(5):785-91. https://doi.org/10.1590/\$0034-89102006000600007

26. Scherrer Jr G, Okuno MFP, Oliveira LM, Barbosa DA, Alonso AC, Fram DS, et al. Quality of life of institutionalized aged with and without symptoms of depression. Rev Bras Enferm. 2019;72(2):127-33. https://doi.org/10.1590/0034-7167-2018-0316

27. Kline RB. Principles and Practice of Structural Equation Modeling. 3rd ed. New York: The Guilford Press; 2012. 445 p.

28. Wang J, Wang X. Structural equation modeling : applications using Mplus. United Kingdom: John Wiley \& Sons; 2012.

29. Browne MW, Cudeck R. Alternative Ways of Assessing Model Fit. Sociol Methods Res. 1992;21(2):230-58. https://doi. org/10.1177/0049124192021002005

30. Hooper D, Coughlan J, Mullen M. Structural equation modelling: Guidelines for determining model fit. Electron J Bus Res Methods. 2008;6(1):53-60. https://doi.org/10.21427/D7CF7R

31. Lee DM, Tajar A, Ravindrarajah R, Pye SR, O'Connor DB, Corona G, et al. Frailty and sexual health in older European men. J Gerontol A Biol Sci Med Sc. 2013;68(7):837-44. https://doi.org/10.1093/gerona/gls217

32. Ricoy-Cano AJ, Obrero-Gaitán E, Caravaca-Sánchez F, Fuente-Robles YM. Factors conditioning sexual behavior in older adults: a systematic review of qualitative studies. J Clin Med. 2020;9(6):1716. https://doi.org/10.3390 / jcm9061716

33. Vasconcellos D, Novo RF, Castro OP, Vion-Dury K, Ruschel Â, Couto MCPP, et al. A sexualidade no processo do envelhecimento: novas perspectivas - comparação transcultural. Estud Psicol. 2004;9(3):413-9. https://doi.org/10.1590/S1413-294X2004000300003

34. Gatti MC, Pinto MJC. Velhice ativa: a vivência afetivo-sexual da pessoa idosa. Vínculo. 2019;16(2):133-59. https://doi.org/10.32467/ issn.19982-1492v16n2p133-159

35. Forbes MK, Eaton NR, Krueger RF. Sexual quality of life and aging: a prospective study of a nationally representative sample. J Sex Res. 2017;54(2):137-48. https://doi.org/10.1080/00224499.2016.1233315

36. Smith L, Yang L, Veronese N, Soysal P, Stubbs B, Jackson SE. Sexual activity is associated with greater enjoyment of life in older adults. Sex Med. 2019;7(1):11-8. https://doi.org/10.1016/j.esxm.2018.11.001

37. Even-Zohar A, Werner S. Older Adults and sexuality in Israel: knowledge, attitudes, sexual activity and quality of life. J Aging Sci. 2019;7(3):209. https://doi.org/10.35248/2329-8847.19.7.209

38. Traeen B, Štulhofer A, Janssen E, Carvalheira AA, Hald GM, Lange T, et al. Sexual activity and sexual satisfaction among older adults in four European Countries. Arch Sex Behav. 2019;48:815-29. https://doi.org/10.1007/s10508-018-1256-x

39. Traeen B, Villar F. Sexual well-being is part of aging well. Eur J Ageing. 2020;17:135-8. https://doi.org/10.1007/s10433-020-00551-0

40. Rodrigues CFCR, Duarte YAO, Rezende FAC, Brito TRP, Nunes DP. Atividade sexual, satisfação e qualidade de vida em pessoas idosas. Rev Eletrôn Enferm. 2019;21:57337. https://doi.org/10.5216/ree.v21.57337

41. Rocha FDA, Fensterseifer L. A função do relacionamento sexual para casais em diferentes etapas do ciclo de vida familiar. Context Clín. 2019;12(2):560-83. https://doi.org/10.4013/ctc.2019.122.08

42. Cambão M, Sousa L, Santos M, Mimoso S, Correia S, Sobral D. QualiSex: estudo da associação entre a qualidade de vida e a sexualidade nos idosos numa população do Porto. Rev Port Med Geral Fam. 2019;35(1):12-20. https://doi.org/10.32385/rpmgf.v35i1.11932

43. Antunes MC, Peres CA, Paiva V, Stall R, Hearst N. Differences in AIDS prevention among young men and women of public schools in Brazil. Rev Saúde Pública. 2002;36(4 SUPPL.):88-95. https://doi.org/10.1590/S0034-89102002000500013

44. Bonin R. Facebook é a rede social mais usada por idosos [Internet]. 2020 [cited 2021 Feb 6]. Available from: https://veja.abril.com.br/blog/ radar/facebook-e-a-rede-social-mais-usada-por-idosos/

45. Queiroz AAFLN, Sousa AFL, Brignol S, Araújo TME, Reis RK. Vulnerability to HIV among older men who have sex with men users of dating apps in Brazil. Braz J Infect Dis. 2019;23(5):298-306. https://doi.org/10.1016/j.bjid.2019.07.005 